\title{
Synthesis and Biological Activity of Hydrochlorides of Benzyl Ethers of Pyrimidin-4(3H)-thiones and Related Compounds
}

\author{
A. V. Erkin ${ }^{a}$, V. V. Gurzhii ${ }^{b}$, and V. I. Krutikov ${ }^{a}$ \\ ${ }^{a}$ St. Petersburg State Technological Institute (Technical University), Moskovskii pr. 26, St. Petersburg 190013 Russia \\ e-mail: kruerk@yandex.ru \\ ${ }^{b}$ St. Petersburg State University, St. Petersburg, Russia
}

Received October 9, 2014

\begin{abstract}
Hydrochlorides of benzyl ether of 2-amino-6-methylpyrimidin-4(3H)-thione and its analogs were synthesized and biological activity of the synthesized compounds was studied.
\end{abstract}

Keywords: pyrimidin-4(3H)-thione, benzylation, hydrochloride, antifungal activity

DOI: $10.1134 / \mathrm{S} 1070363215010144$

Among effective inhibitors of biological objects of viral and microbial nature pyrimidin-4(3H)-thiones and their ethers with various substituents in the ring attract great attention [1-3]. Some representatives of these compounds were considered earlier $[4,5]$ as potential antitumor agents. In continuation of the studies of the pyrimidin-4(3H)-thione derivatives, in the present work we have synthesized hydrochlorides of 2-amino-4-benzylthio-6-methylpyrimidine (Ia) and its analogs (Ib-Ie), and their biological activity towards a series of pathogenic cultures, Escherichia coli, Mycobacterium tuberculosis, and Candida albicans, was studied (Scheme 1).

Hydrochlorides Ia-Id were obtained by passing gaseous hydrogen chloride through the solutions of the corresponding free bases IIa-IId in anhydrous

\section{Scheme 1.}

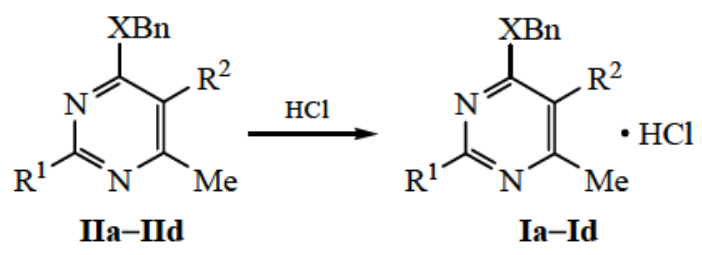

$\mathrm{R}^{1}=\mathrm{H}_{2} \mathrm{~N}, \mathrm{R}^{2}=\mathrm{H}, \mathrm{X}=\mathrm{S}\left(\right.$ a) $; \mathrm{R}^{1}=\mathrm{H}_{2} \mathrm{~N}, \mathrm{R}^{2}=\mathrm{Br}, \mathrm{X}=\mathrm{S}$ (b); $\mathrm{R}^{1}=\mathrm{R}^{2}=\mathrm{H}, \mathrm{X}=\mathrm{S}(\mathbf{c}) ; \mathrm{R}^{1}=\mathrm{H}_{2} \mathrm{~N}, \mathrm{R}^{2}=\mathrm{H}, \mathrm{X}=\mathrm{O}(\mathbf{d})$; $\mathrm{Bn}=\mathrm{PhCH}_{2}$. benzene at room temperature. Compound Id could not be isolated in crystalline state because of its high hygroscopicity. The treatment of the oily substance of this hydrochloride with excess of $25 \%$ aqueous ammonia led to regeneration of the starting benzyloxypyrimidine IId.

The formation of 2-amino-4-benzylamino-6-methylpyrimidine hydrochloride Id occurred directly at the condensation of 2-amino-4-chloro-6-methylpyrimidine (III) with benzylamine in $1: 1$ molar ratio of the components in the absence of solvent at $130^{\circ} \mathrm{C}$ (Scheme 2).

Limiting the time of contact of 2-amino-6-methylpyrimidin-4(3H)-one (IV) with phosphorus oxy-

\section{Scheme 2.}<smiles>Cc1cc(=O)[nH]c(N)n1</smiles>

IV<smiles>Cc1cc(Cl)nc(N)n1</smiles>

III<smiles>Cc1cc(Cc2ccccc2)nc(N)n1</smiles> 
Scheme 3.<smiles>Cc1cc(Cl)nc(NC=O)n1</smiles>

Scheme 4.<smiles></smiles><smiles>Cc1cc(=O)[nH]c(=S)[nH]1</smiles>

IX<smiles></smiles>

XIII

$\mathrm{Ar}=2,4,6-\left(\mathrm{O}_{2} \mathrm{~N}\right)_{3} \mathrm{C}_{6} \mathrm{H}_{2}$.

chloride to the period of homogenization of the reaction mixture allowed to avoid the processes of $\mathrm{N}$ and O-phosphorylation, which were noted in [6] during the exchange chlorination of compound (IV) by the method described in [7].

The synthesis of free bases IIa, IIb was performed by S-benzylation of 2-amino-6-methylpyrimidin4(3H)-thione (V) with benzyl chloride in aqueous ethanol solution in the presence of sodium hydroxide with subsequent bromination of compound IIa with $N$ bromosuccinimide (NBS) in tetrachloromethane (Scheme 3).

Isothiocytosine $\mathbf{V}$ required for the reaction was prepared by alkaline hydrolysis of isothiouronium salt VII, which was obtained by condensation of 4-chloro2-formylamino-6-methylpyrimidine (VI) [6] with thiourea in boiling ethanol. The IR spectrum of compound VII contained the bands of stretching vibrations of the quaternized amidinium fragment in the range $2603-2652$ and $2340-2360 \mathrm{~cm}^{-1}$, as well as the bands "amide I" and "amide II" at 1664 and $1549 \mathrm{~cm}^{-1}$ respectively.

The use of pyrimidine VI in the reaction allows to avoid the formation of bis(2-amino-6-methylpyrimidin-4-yl)sulfide at heating compound III with thiourea in ethanol [8]. Other methods of synthesis of isothiocytosine $\mathbf{V}$ included treatment of aminochloropyrimidine III with sodium hydrosulfide in ethylene glycol [5] and sulfidation of compound IV with the Lawesson reagent, 2,4-bis(4-methoxyphenyl)-[1,2,3,4]dithiadiphosphetane-2,4-disulfide, in 1,4-dioxane [9]. Taking into account the necessity of preliminary preparation of the above sulfidating reagents [5, 9], and of performing the reaction in a heterogeneous medium [9], the aforementioned methods seem hardly acceptable.

The synthesis of free base IIc included S-benzylation of 6-methylpyrimidin-4(3H)-thione (VIII) under the conditions described for isothiocytosine $\mathbf{V}$. Thiopyrimidine VIII, in turn, was prepared by 
Scheme 5.

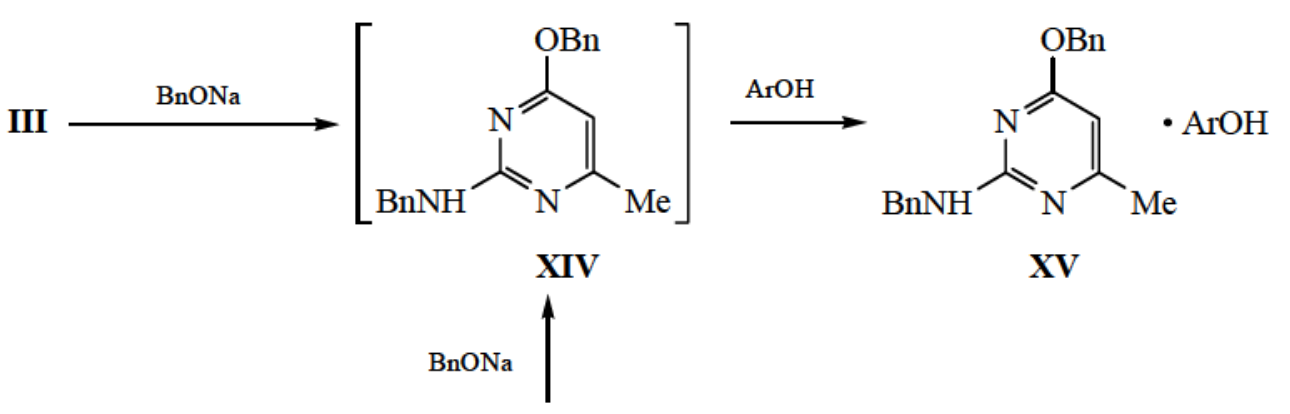<smiles>Cc1cc(Cl)nc(NCc2ccccc2)n1</smiles>

$$
\mathrm{Ar}=2,4,6-\left(\mathrm{O}_{2} \mathrm{~N}\right)_{3} \mathrm{C}_{6} \mathrm{H}_{2} \text {. }
$$

successive transformations of compounds IX-XIII according to method [10] modifying some stages.

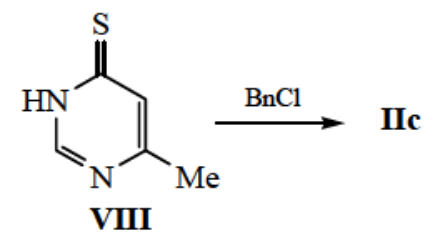

Oxidative desulfurization of 6-methyl-2-thioxo-1,2dihydropyrimidin-4(3H)-one (IX) with hydrogen peroxide in water gave 6-methylpyrimidin-4 $(3 H)$-one $(\mathbf{X})$ isolated from the reaction mixture as picrate $\mathbf{X I}$. The hydrolysis of complex compound XI with conc. hydrochloric acid resulted in the formation of hydrochloride of 6-methylpyrimidin-4(3H)-one XII, which after treatment with phosphorus oxychloride was converted into 4-chloro-6-methyl XIII. The condensation of chloropyrimidine XIII with thiourea in ethanol led directly to thiopyrimidine VIII; no formation of the intermediate isothiouronium salt was observed [10] (Scheme 4).

We have modified the stages of isolation and exchange chlorination of pyrimidinone $\mathbf{X}$. In view of a high volatility [11], compound $\mathbf{X}$ was isolated from aqueous solution as picrate $\mathbf{X I}$. By the same reason, the exchange chlorination was performed with hydrochloride XII rather than pyrimidinone $\mathbf{X}$.

The free base IId was obtained by heating the mixture of aminochloropyrimidine III with 3-fold excess of sodium benzylate in benzyl alcohol at $140^{\circ} \mathrm{C}$.
The reaction proceeded as $N$-benzylation of the substrate with the formation of 2-benzylamino-4benzyloxy-6-methylpyrimidine XIV, which was isolated in the crystalline form after the treatment of the reaction mixture with picric acid $(\operatorname{method} a) .{ }^{1} \mathrm{H}$ NMR spectrum of picrate XV contains characteristic signals of protons of $\mathrm{CH}_{2}$ and $\mathrm{NH}$ groups in the region $4.6-5.5 \mathrm{ppm}$ and at $8.6 \mathrm{ppm}$, respectively, with the integral intensity ratio $4: 1$. Finally, compound XV was identified by coincidence of its physicochemical and spectral parameters with those determined for the authentic sample of picrate $\mathbf{X V}$. The latter was prepared by authentic synthesis, that is, by the reaction of 2-benzylamino-4-chloro-6-methylpyrimidine (XVI) [12] with 3-fold excess of sodium benzylate in benzyl alcohol at $140^{\circ} \mathrm{C}$ with a subsequent quaternization of $\mathrm{N}, \mathrm{O}$-dibenzylisocytosine $\mathbf{X I V}$ with picric acid (method b). Examples of successful $N$-benzylation of some (hetero)aromatic amines with benzyl alcohol under similar conditions are described in the literature [13] (Scheme 5).

An attempt to displace the chlorine atom in the formyl derivative of aminochloropyrimidine III by the benzyloxy group failed. After completion of heating the reaction mixture of compound VI with 3 -fold excess of sodium benzylate in benzyl alcohol at $140^{\circ} \mathrm{C}$ during $4 \mathrm{~h}$ a product was isolated, which was chromatographically identical to the initial substrate; the mixing probe with compound VI showed no depression of the melting point. The same result was obtained when DMF was used as the solvent. 
Crystallography data and structure refinement parameters for 2-amino-3-benzyl-6-methylpyrimidin-4(3H)-one (XVII)

\begin{tabular}{|c|c|}
\hline Parameter & Value \\
\hline Formula & $\left(\mathrm{C}_{12} \mathrm{H}_{13} \mathrm{~N}_{3} \mathrm{O}\right)_{2} \cdot \mathrm{H}_{2} \mathrm{O}$ \\
\hline Crystal system & Monoclinic \\
\hline$a, \AA$ & $14.7885(6)$ \\
\hline$b, \AA$ & $9.9806(3)$ \\
\hline$c, \AA$ & $17.3608(7)$ \\
\hline$\alpha, \operatorname{deg}$ & 90 \\
\hline$\beta, \operatorname{deg}$ & $114.864(5)$ \\
\hline$\gamma, \operatorname{deg}$ & 90 \\
\hline$V, \AA^{3}$ & $2324.88(17)$ \\
\hline Molecular mass & 448.52 \\
\hline Space group & $P 2_{1} / c$ \\
\hline$\mu, \mathrm{mm}^{-1}$ & 0.088 \\
\hline Temperature, $\mathrm{K}$ & $100(2)$ \\
\hline$Z$ & 4 \\
\hline$d_{\text {calc }}, \mathrm{g} / \mathrm{cm}^{3}$ & 1.281 \\
\hline Crystal size, $\mathrm{mm}^{3}$ & $0.25 \times 0.18 \times 0.14$ \\
\hline Radiation & $\operatorname{Mo} K_{\alpha}$ \\
\hline Total reflections & 21307 \\
\hline Independent reflections & 5327 \\
\hline Range of measurements $2 \theta$, deg & $5.09-55.00$ \\
\hline Reflections with $\left|F_{0}\right| \geq 4 \sigma_{F}$ & 3929 \\
\hline$R_{\text {int }}$ & 0.0516 \\
\hline$R_{\sigma}$ & 0.0675 \\
\hline$R_{1}\left(\left|F_{0}\right| \geq 4 \sigma_{F}\right)$ & 0.0480 \\
\hline$w R_{2}\left(\left|F_{0}\right| \geq 4 \sigma_{F}\right)$ & 0.0951 \\
\hline$R_{1}\left(\right.$ for all data) ${ }^{\mathrm{a}}$ & 0.0740 \\
\hline$w R_{2}$ (for all data) ${ }^{\mathrm{b}}$ & 0.1080 \\
\hline$S$ & 1.056 \\
\hline$\rho_{\min }, \rho_{\max }, e / \AA^{3}$ & $-0.261,0.247$ \\
\hline
\end{tabular}

${ }^{\mathrm{a}} R_{1}=\Sigma|| F_{0}|-| F_{\mathrm{c}}|/ \Sigma| F_{0} \mid{ }^{\mathrm{b}} w R_{2}=\left\{\Sigma\left[w\left(F_{0}^{2}-F_{\mathrm{c}}^{2}\right)^{2}\right] / \Sigma\left[w\left(F_{0}^{2}\right)^{2}\right]\right\}^{1 / 2}$; $w=1 /\left[\sigma^{2}\left(F_{0}^{2}\right)+(a P)^{2}+b P\right]$, where $P=\left(F_{0}^{2}+2 F_{\mathrm{c}}^{2}\right) / 3 ; s=$ $\left\{\Sigma\left[w\left(F_{0}^{2}-F_{\mathrm{c}}^{2}\right)\right] /(n-p)\right\}^{1 / 2}$, where $n$ denotes the number of reflections and $p$ is the number of refined parameters.
An alternative method for the preparation of the free base IId consisted in $O$-benzylation of isocytosine IV with benzyl chloride in DMF in the presence of sodium hydride $[14,15]$. The replacement of the latter by the more available potassium carbonate resulted in the formation of the mixture of compound IId and 2amino-3-benzyl-6-methylpyrimidin-4(3H)-one (XVII) as a minor product, which was separated by fractional crystallization.

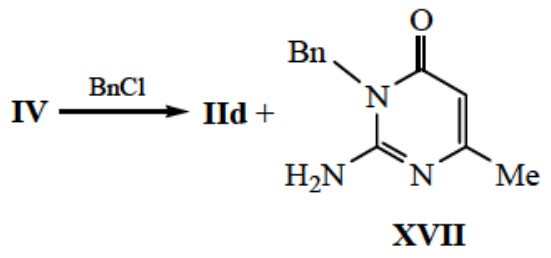

The structure of $N$-benzylisocytosine XVII was proved by X-ray diffraction (XRD) analysis. According to the XRD (see the table), the crystal of compound XVII consists of the dimers of crystallographically equivalent molecules connected by hydrogen bonds between the proton of the exocyclic atom $\mathrm{N}^{7}$ and atom $\mathrm{N}^{1}$ of the adjacent molecule. The formation of the crystal lattice of $\mathrm{N}$-benzylisocytosine XVII occurs by binding the dimers through H-bonding interactions between the oxygen atom $\mathrm{O}^{9}$ of one monomer unit, the proton of crystallization water, the oxygen atom of the latter, and the proton of $\mathrm{N}^{7 \mathrm{~A}}$ atom of another unit (see the figure). The formation of hydrogen bonds of the above-mentioned type can explain the splitting of the $\mathrm{C}=\mathrm{O}$ group stretching vibration bands and bending vibrations of the amino group observed in the IR spectrum of the crystalline sample of compound XVII.

The results of biological screening of hydrochlorides Ia-Ic, Ie showed their inability to inhibit the cell growth of Escherichia coli and Mycobacterium tuberculosis in concentrations up to $100 \mathrm{mkg} / \mathrm{mL}$. At the same time, compound Ia showed a pronounced antifungal activity with respect to Candida albicans [minimal concentration leading to $100 \%$ inhibition of the biological object $\left(\mathrm{MIC}_{100}\right)$ was $\left.25 \mu \mathrm{g} / \mathrm{mL}\right]$. Compound $\mathbf{I b}$ was inactive in the range of concentrations $1-100 \mu \mathrm{g} / \mathrm{mL}$. In going from hydrochloride Ia to compound Ic the value of $\mathrm{MIC}_{100}$ increased twice. Formal replacement of the sulfur atom in hydrochloride Ia by the secondary amino group was followed by the loss of antifungal activity of compound $\mathbf{I}$ in the above range of concentrations. 


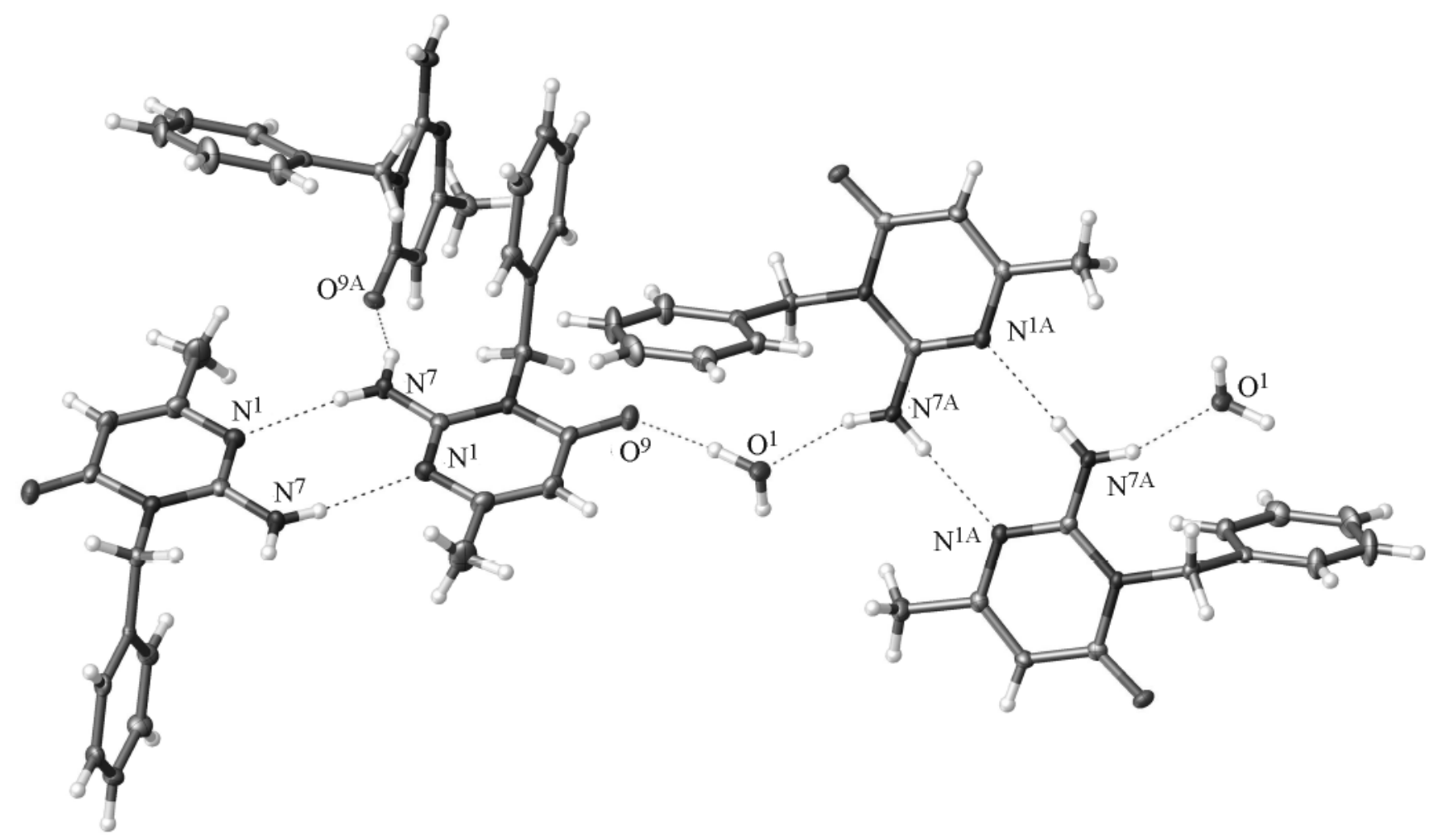

Structure of crystal lattice of 2-amino-3-benzyl-6-methylpyrimidin-4(3H)-one (XVII).

\section{EXPERIMENTAL}

${ }^{1} \mathrm{H}$ NMR spectra were registered on a Bruker WM400 spectrometer (working frequency $400.13 \mathrm{MHz}$ ) in DMSO- $d_{6}$, the signals of residual protons of the solvent served as internal reference. IR spectra were taken on a Shimadzu FTIR-8400S spectrophotometer in $\mathrm{KBr}$. The purity and identity of the compounds were monitored by TLC on Silufol UV-254 and Sorbfil PTSKh-AF-V-UV plates (compounds IId, III, and XVII) in the systems 1-butanol-acetic acid-water, $1: 1: 1$ (eluent A), 2-propanol-25\% aqueous ammonia, $3: 1$ (eluent B), acetone-hexane, $1: 1$ (eluent C), and acetone-hexane, $2: 1$ (eluent D). The plates were visualized by UV irradiation at $254 \mathrm{~nm}$. Elemental analyses were performed on a Hewlett Packard 185B CHN-analyzer. Aqueous or aqueousethanol solutions of hydrochlorides Ia-Ie and XII, as well as of salt VII gave positive test on the presence of chloride ions when treated with aqueous silver nitrate.

$\mathrm{X}$-ray structural analysis was performed in the Resource center of St. Petersburg State University "X-ray diffraction Studies" using the Agilent Technologies Excalibur Eos single crystal diffractometer equipped with CCD-detector. The measurements were performed at $100 \mathrm{~K}$ using monochromated $\mathrm{Mo} K_{\alpha}$-radiation. The elementary cell parameters (see the table) were refined by the least-squares method from 21307 reflections with $2 \theta$ varied from $5.09^{\circ}$ to $55.00^{\circ}$. The structure was solved by the direct method and refined to $R_{1} 0.048$ $\left(w R_{2} 0.095\right)$ for 3929 independent reflections with $\left|F_{0}\right| \geq$ $4 \sigma_{F}$ using SHELXL-97 program [16] implemented in OLEX2 package [17]. Extinction corrections were performed using program package CrysAlisPro [18]. The positions of hydrogen atoms were calculated using SHELX software, where $U_{\text {iso }}(\mathrm{H})=1.5 U_{\text {eq }}(\mathrm{C})$ and C-H $0.96 \AA$ for $\mathrm{CH}_{3}$ groups, $U_{\text {iso }}(\mathrm{H})=1.2 U_{\text {eq }}(\mathrm{C})$ and $\mathrm{C}-\mathrm{H}$ $0.97 \AA$ for $\mathrm{CH}_{2}$ groups, $U_{\text {iso }}(\mathrm{H})=1.2 U_{\text {eq }}(\mathrm{C})$ and $\mathrm{C}-\mathrm{H}$ $0.93 \AA$ for $\mathrm{CH}$ groups and $U_{\text {iso }}(\mathrm{H})=1.2 U_{\text {eq }}(\mathrm{N})$ and $\mathrm{N}-\mathrm{H} 0.86 \AA$ for $\mathrm{NH}_{2}$ groups. Hydrogen atoms of crystallization water molecule were localized objectively and refined without restrictions with individual thermal parameters. Crystallographic data and structure refinement parameters were deposited to the Cambridge Crystallographic Data Centre (CCDC 1018711) and can be obtained free of charge via www.ccdc.cam.ac.uk/data_request/cif.

2-Amino-4-benzylthio-6-methylpyrimidine hydrochloride (Ia). Through a solution of $0.15 \mathrm{~g}$ of 2-amino-4benzylthio-6-methylpyrimidine IIa in $15 \mathrm{~mL}$ of anhyd- 
rous benzene dry hydrogen chloride was passed to saturation. After removal of the solvent in a vacuum the residue was treated with $5 \mathrm{~mL}$ of cyclohexane, the precipitate was filtered off and dried to a constant mass. Yield $0.12 \mathrm{~g}(70 \%), \mathrm{mp} 180^{\circ} \mathrm{C}, R_{\mathrm{f}} 0.76$ (A). Found, \%: C 53.15; H 5.21; N 15.59. $\mathrm{C}_{12} \mathrm{H}_{13} \mathrm{~N}_{3} \mathrm{~S} \cdot \mathrm{HCl}$. Calcd, \%: C 53.82; H 5.27; N 15.69.

2-Amino-4-benzylthio-5-bromo-6-methylpyrimidine hydrochloride (Ib). Through a solution of $0.13 \mathrm{~g}$ of 2amino-4-benzylthio-5-bromo-6-methylpyrimidine IIb in $15 \mathrm{~mL}$ of anhydrous benzene dry hydrogen chloride was passed to saturation. The formed suspension was filtered, the filtrate was concentrated in a vacuum to half of the initial volume, the formed precipitate was filtered off, combined with the main portion of the product, washed with $5 \mathrm{~mL}$ of cyclohexane, and dried to a constant mass. Yield $80 \mathrm{mg}(57 \%), \mathrm{mp} 184^{\circ} \mathrm{C}, R_{\mathrm{f}}$ 0.88 (A). Found, \%: C 41.29; H 4.05; N 11.82 . $\mathrm{C}_{12} \mathrm{H}_{12} \mathrm{BrN}_{3} \mathrm{~S} \cdot \mathrm{HCl}$. Calculated, \%: C 41.58; H 3.78; N 12.12 .

\section{4-Benzylthio-6-methylpyrimidine hydrochloride} (Ic). To a solution of $0.3 \mathrm{~g}$ of thiopyrimidine VIII in $18 \mathrm{~mL}$ of water containing $2 \mathrm{~g}$ of sodium hydroxide $0.3 \mathrm{~g}$ of benzyl chloride in $3 \mathrm{~mL}$ of ethanol was added dropwise with vigorous stirring. The mixture was kept at $80^{\circ} \mathrm{C}$ for $1 \mathrm{~h}$ and cooled to room temperature. 4-Benzylthio-6-methylpyrimidine IIc formed as an oily substance was extracted with $20 \mathrm{~mL}$ of benzene. The organic layer was separated and dried over calcium chloride for 1 day. The drier was separated, dry hydrogen chloride was passed through the solution to saturation, benzene was removed in a vacuum, the residue was treated with $10 \mathrm{~mL}$ of the $1: 1$ mixture of benzene and cyclohexane. The precipitate was washed with $5 \mathrm{~mL}$ of cyclohexane and dried to a constant mass. Yield $0.35 \mathrm{~g}(59 \%), \mathrm{mp} 147^{\circ} \mathrm{C}, R_{\mathrm{f}} 0.85$ (A). ${ }^{1} \mathrm{H}$ NMR spectrum, $\delta$, ppm: $2.47 \mathrm{~s}(3 \mathrm{H}, \mathrm{Me}), 4.52 \mathrm{~s}(2 \mathrm{H}$, $\left.\mathrm{CH}_{2}\right), 7.24-7.44 \mathrm{~m}(5 \mathrm{H}, \mathrm{Ph}), 7.58 \mathrm{~s}\left(1 \mathrm{H}, \mathrm{C}^{5} \mathrm{H}\right), 9.00 \mathrm{~s}$ $\left(1 \mathrm{H}, \mathrm{C}^{2} \mathrm{H}\right)$. Found, \%: C 56.59; H 4.87; N 10.77 . $\mathrm{C}_{12} \mathrm{H}_{12} \mathrm{~N}_{2} \mathrm{~S} \cdot \mathrm{HCl}$. Calculated, \%: C 57.02; H 5.18; N 11.08 .

2-Amino-4-benzylamino-6-methylpyrimidine hydrochloride (Ie). The mixture of $0.5 \mathrm{~g}$ of aminochloropyrimidine III and $0.37 \mathrm{~g}$ of freshly distilled benzylamine was kept at $130^{\circ} \mathrm{C}$ for $1 \mathrm{~h}$. After cooling, the solidified reaction mass was crushed, dispersed in benzene, and filtered. The precipitate was crystallized from the mixture benzene-ethanol $(7: 1)$ and dried to a constant mass. Yield $0.5 \mathrm{~g}(57 \%), \mathrm{mp} 156^{\circ} \mathrm{C}, R_{\mathrm{f}} 0.80$ (A). ${ }^{1} \mathrm{H}$ NMR spectrum, $\delta$, ppm: $2.22 \mathrm{~s}(3 \mathrm{H}, \mathrm{Me}), 4.59$ d $\left(2 \mathrm{H}, \mathrm{CH}_{2} \mathrm{NH}, J 6.0 \mathrm{~Hz}\right), 6.00 \mathrm{~s}(1 \mathrm{H}, \mathrm{CH}), 7.23-7.66$ m (7H, Ph, $\left.\mathrm{NH}_{2}\right), 9.21 \mathrm{t}(1 \mathrm{H}, \mathrm{NH}, J 11.0 \mathrm{~Hz}), 12.75$ br.s $\left(1 \mathrm{H}, \mathrm{N}^{+} \mathrm{H}\right)$. Found, \%: C 57.13; H 6.18; N 22.14. $\mathrm{C}_{12} \mathrm{H}_{14} \mathrm{~N}_{4} \cdot \mathrm{HCl}$. Calculated, \%: C 57.48; H $6.03 ; \mathrm{N}$ 22.35 .

2-Amino-4-benzylthio-6-methylpyrimidine (IIa). To a solution of $0.4 \mathrm{~g}$ of isothiocytosine $\mathbf{V}$ in $10 \%$ aqueous sodium hydroxide prepared from $2 \mathrm{~g}$ of $\mathrm{NaOH}$ $0.34 \mathrm{~g}$ of benzyl chloride in $3 \mathrm{~mL}$ of ethanol was added dropwise at vigorous stirring. The mixture was kept at $80^{\circ} \mathrm{C}$ for $1 \mathrm{~h}$, cooled, and the formed slurry was filtered. The precipitate was washed with water, dried at $70^{\circ} \mathrm{C}$ for $4 \mathrm{~h}$, crystallized from cyclohexane, and dried to a constant mass. Yield $0.41 \mathrm{~g}(62 \%), \mathrm{mp} 123^{\circ} \mathrm{C}$ (mp $\left.118-120^{\circ} \mathrm{C}[5]\right), R_{\mathrm{f}} 0.80$ (B). ${ }^{1} \mathrm{H}$ NMR spectrum, $\delta$, ppm: $2.14 \mathrm{~s}(3 \mathrm{H}, \mathrm{Me}), 4.35 \mathrm{~s}\left(2 \mathrm{H}, \mathrm{CH}_{2}\right), 6.35 \mathrm{~s}(1 \mathrm{H}$, $\mathrm{CH}), 6.53 \mathrm{~s}\left(2 \mathrm{H}, \mathrm{NH}_{2}\right), 7.22-7.43 \mathrm{~m}(5 \mathrm{H}, \mathrm{Ph})$.

2-Amino-4-benzylthio-5-bromo-6-methylpyrimidine (IIb). A mixture of $0.4 \mathrm{~g}$ of free base IIa and $0.3 \mathrm{~g}$ of $N$-bromosuccinimide [19] in $15 \mathrm{~mL}$ of tetrachloromethane was refluxed for $1 \mathrm{~h}$. The formed slurry was cooled to room temperature and allowed to stay overnight. The precipitate was filtered off, crystallized from $65 \%$ ethanol, and dried to a constant mass. Yield $0.125 \mathrm{~g}(24 \%), \mathrm{mp} 141^{\circ} \mathrm{C}\left(\mathrm{mp} 135-137^{\circ} \mathrm{C}\right.$ [5]), $R_{\mathrm{f}} 0.51(\mathrm{C}) .{ }^{1} \mathrm{H}$ NMR spectrum, $\delta$, ppm: $2.30 \mathrm{~s}$ $(3 \mathrm{H}, \mathrm{Me}), 4.34 \mathrm{~s}\left(2 \mathrm{H}, \mathrm{CH}_{2}\right), 6.76 \mathrm{~s}\left(2 \mathrm{H}, \mathrm{NH}_{2}\right), 7.22-$ $7.46 \mathrm{~m}(5 \mathrm{H}, \mathrm{Ph})$.

2-Amino-4-benzyloxy-6-methylpyrimidine (IId). A mixture of $1.5 \mathrm{~g}$ of isocytosine $\mathbf{I V}, 1.52 \mathrm{~g}$ of benzyl chloride, and 0.83 of calcined potassium carbonate in $25 \mathrm{~mL}$ of anhydrous DMF was kept at $80^{\circ} \mathrm{C}$ for $4 \mathrm{~h}$. After cooling to room temperature the precipitate was filtered off, the filtrate was evaporated in a vacuum to dryness. The residue was ground with $5 \%$ solution of sodium hydroxide, the insoluble part was filtered off, thoroughly washed with water, and dried to a constant mass to obtain a mixture of compound IId and $\mathrm{N}$ benzylisocytosine XVII, which was separated by treatment with $10 \mathrm{~mL}$ of acetonitrile with subsequent filtering off an insignificant insoluble residue. The precipitate separated from the solution after staying was filtered off, washed with a minimal amount of acetonitrile, and dried to a constant mass. From the filtrate, acetonitrile was removed, the residue was treated with benzene, the insoluble part was filtered 
off, benzene was removed in a vacuum. The residue was crystallized from cyclohexane and dried to constant mass. Yield $0.17 \mathrm{~g}, \mathrm{mp} 107^{\circ} \mathrm{C}$ (mp 108$\left.109.5^{\circ} \mathrm{C}[14], 110-112^{\circ} \mathrm{C}[15]\right), R_{\mathrm{f}} 0.61$ (D). ${ }^{1} \mathrm{H}$ NMR spectrum, $\delta$, ppm: $2.16 \mathrm{~s}(3 \mathrm{H}, \mathrm{Me}), 5.29 \mathrm{~s}\left(2 \mathrm{H}, \mathrm{CH}_{2}\right)$, $5.83 \mathrm{~s}(1 \mathrm{H}, \mathrm{CH}), 6.34 \mathrm{~s}\left(2 \mathrm{H}, \mathrm{NH}_{2}\right), 7.28-7.40 \mathrm{~m}(5 \mathrm{H}$, $\mathrm{Ph})$.

2-Amino-4-chloro-6-methylpyrimidine (III). A mixture of $6 \mathrm{~g}$ of isocytosine IV and $35 \mathrm{~mL}$ of freshly distilled phosphorus oxychloride was refluxed till the mixture became homogeneous, then the excess of the chlorinating agent was removed in a vacuum. For cooling, the residue was mixed with ice and treated with $25 \%$ aqueous ammonia to $\mathrm{pH} 8$. The formed suspension was filtered, the precipitate was washed with water, crystallized from $50 \%$ ethanol, and dried to a constant mass. Yield $3.7 \mathrm{~g}(54 \%), \mathrm{mp} 188^{\circ} \mathrm{C}(\mathrm{mp}$ $182-183^{\circ} \mathrm{C}$ [7]), $R_{\mathrm{f}} 0.79$ (D). Found, \%: C $41.74 ; \mathrm{H}$ 4.05; $\mathrm{N} 29.35$. $\mathrm{C}_{5} \mathrm{H}_{6} \mathrm{ClN}_{3}$. Calculated, \%: C 41.83; $\mathrm{H}$ $4.21 ; \mathrm{N} 29.27$.

2-Amino-6-methylpyrimidin-4(3H)-thione (V). A mixture of $2.02 \mathrm{~g}$ of isothiouronium salt VII and $10 \%$ solution of potassium hydroxide prepared from $7 \mathrm{~g}$ of $\mathrm{KOH}$ was refluxed to homogeneous state. The reaction mixture was filtered from small impurities and evaporated to dryness in a vacuum. The residue was dispersed in $20 \mathrm{~mL}$ of water and treated with acetic acid to $\mathrm{pH}$ 6-7. The precipitate was filtered off, washed with water, and dried to a constant mass to give $0.98 \mathrm{~g}(85 \%)$ of isothiocytosine $\mathbf{V}$ with $\mathrm{mp}>250^{\circ} \mathrm{C}$ (decomp.) (mp $321^{\circ} \mathrm{C}[5],>190^{\circ} \mathrm{C}$ (decomp.) [9]), $R_{\mathrm{f}}$ 0.43 (B), which was used in S-benzylation without additional purification. Analytically pure sample of compound $\mathbf{V}$ was obtained by crystallization from $30 \%$ acetic acid with subsequent thorough washing with water and drying at $70^{\circ} \mathrm{C}$ for $10 \mathrm{~h}, \mathrm{mp}>250^{\circ} \mathrm{C}$ (decomp.). ${ }^{1} \mathrm{H}$ NMR spectrum, $\delta$, ppm: $2.06 \mathrm{~s}(3 \mathrm{H}$, $\mathrm{Me}), 6.31 \mathrm{~s}(1 \mathrm{H}, \mathrm{CH}), 6.76 \mathrm{~s}\left(2 \mathrm{H}, \mathrm{NH}_{2}\right), 11.91$ br.s $(1 \mathrm{H}, \mathrm{NH})$. Found, \%: C 42.34; H 5.08; N 29.67. $\mathrm{C}_{5} \mathrm{H}_{7} \mathrm{~N}_{3}$ S. Calculated, \%: C 42.53; H 5.00; N 29.76.

(2-Formylamino-6-methylpyrimidin-4-yl)isothiouronium chloride (VII). A mixture of $2.3 \mathrm{~g}$ of pyrimidine VI and $1.02 \mathrm{~g}$ of thiourea in $25 \mathrm{~mL}$ of ethanol was refluxed for $3 \mathrm{~h}$. After cooling the formed precipitate was filtered off, washed with ethanol, and dried to a constant mass to give $2.02 \mathrm{~g}(61 \%)$ of isothiouronium salt VII, $\mathrm{mp} 237^{\circ} \mathrm{C}$ (decomp.), $R_{f} 0.43$ (B), which was used in the preparation of isothio- cytosine $\mathbf{V}$ without further purification. Analytically pure sample of compound VII was prepared by crystallization from the mixture of ethanol and DMF (1:4) with subsequent thorough washing with anhydrous diethyl ether and drying to a constant mass, $\mathrm{mp} 240^{\circ} \mathrm{C}$ (decomp.). IR spectrum, $v, \mathrm{~cm}^{-1}: 3081 \mathrm{~m}$ $\left(\mathrm{C}^{5} \mathrm{H}\right), 2652,2603,2359,2344 \mathrm{~m}\left(\mathrm{NH}_{2}{ }^{+}, \mathrm{NH}^{+}\right), 1664 \mathrm{~s}$ $(\mathrm{C}=\mathrm{O}), 1549 \mathrm{~s}(\mathrm{NH})$. Found, \%: C 33.37; H 4.17; N 27.86. $\mathrm{C}_{7} \mathrm{H}_{9} \mathrm{~N}_{5} \mathrm{OS} \cdot \mathrm{HCl}$. Calculated, \%: C 33.94; $\mathrm{H}$ $4.07 ; \mathrm{N} 28.27$.

6-Methylpyrimidin-4(3H)-one picrate (XI). To a $3-4 \%$ solution of hydrogen peroxide $(50 \mathrm{~mL})$ heated to $70^{\circ} \mathrm{C} 6 \mathrm{~g}$ of thiouracil IX was added by portions in the course of $30 \mathrm{~min}$ with vigorous stirring. After the addition was completed, the reaction mixture was kept at this temperature for $15 \mathrm{~min}$, then cooled and neutralized with $10 \%$ aqueous solution of sodium hydroxide. The obtained solution was heated to $70^{\circ} \mathrm{C}$ and treated with $9.7 \mathrm{~g}$ of picric acid. The mixture was stirred at $90^{\circ} \mathrm{C}$ for $15 \mathrm{~min}$ to homogeneous state. After cooling to room temperature the formed suspension was kept for no less than $5 \mathrm{~h}$, then filtered. The obtained precipitate was twice crystallized from water and dried to a constant mass. Yield $7.3 \mathrm{~g}(51 \%), \mathrm{mp}$ $147^{\circ} \mathrm{C}, R_{\mathrm{f}} 0.81$ (A). Found, \%: C 38.47; H 2.69; N 20.12. $\mathrm{C}_{5} \mathrm{H}_{6} \mathrm{~N}_{2} \mathrm{O} \cdot \mathrm{C}_{6} \mathrm{H}_{3} \mathrm{~N}_{3} \mathrm{O}_{7}$. Calculated, \%: C 38.95; $\mathrm{H}$ $2.67 ; \mathrm{N} 20.65$.

4-Chloro-6-methylpyrimidine (XII). A mixture of $7.3 \mathrm{~g}$ of picrate $\mathbf{X I}, 100 \mathrm{~mL}$ of diluted $(1: 1)$ hydrochloric acid, and $50 \mathrm{~mL}$ of benzene was refluxed with vigorous stirring for $15 \mathrm{~min}$. After cooling to room temperature the aqueous layer was separated, filtered from small amount of precipitated picric acid, and evaporated to dryness in a vacuum. The residue was refluxed with $50 \mathrm{~mL}$ of anhydrous acetonitrile, the insoluble part filtered from hot solution, washed with acetonitrile, and dried to a constant mass. Yield $2.54 \mathrm{~g}$ (80\%), mp $222^{\circ} \mathrm{C}, R_{\mathrm{f}} 0.65$ (A). ${ }^{1} \mathrm{H}$ NMR spectrum, $\delta$, ppm: $2.81 \mathrm{~s}(3 \mathrm{H}, \mathrm{Me}), 6.88 \mathrm{~s}\left(1 \mathrm{H}, \mathrm{C}^{5} \mathrm{H}\right), 9.48 \mathrm{~s}(1 \mathrm{H}$, $\left.\mathrm{C}^{2} \mathrm{H}\right), 9.74$ br.s $\left(2 \mathrm{H}, \mathrm{NH}, \mathrm{N}^{+} \mathrm{H}\right)$. Found, \%: C 40.54; $\mathrm{H}$ 4.60; $\mathrm{N}$ 18.92. $\mathrm{C}_{5} \mathrm{H}_{7} \mathrm{~N}_{2} \mathrm{O} \cdot \mathrm{HCl}$. Calculated, \%: C 40.97; $\mathrm{H} 4.81$; N 19.11 .

4-Methyl-6-chloropyrimidine (XIII) was prepared similarly to compound III from $5 \mathrm{~g}$ of hydrochloride XII and $25 \mathrm{~mL}$ of freshly distilled phosphorus oxychloride. After treatment of the reaction mixture with $25 \%$ aqueous ammonia to $\mathrm{pH} 8$ the product was extracted with dichloromethane $(2 \times 20 \mathrm{~mL})$, the 
organic layer dried over calcium chloride for $10 \mathrm{~h}$, dichloromethane was removed, the residue was distilled in a vacuum collecting the fraction with $\mathrm{mp}$ $97-100^{\circ} \mathrm{C}(20 \mathrm{mmHg})$. Yield $3.29 \mathrm{~g}(75 \%), \mathrm{mp} 35^{\circ} \mathrm{C}$ (mp 38-39 $\left.{ }^{\circ} \mathrm{C}[7], 34.5-36^{\circ} \mathrm{C}[10]\right), R_{\mathrm{f}} 0.69(\mathrm{C})$.

2-Benzylamino-4-benzyloxy-6-methylpyrimidine picrate (XV). $a$. To a solution of $0.24 \mathrm{~g}$ of sodium in $30 \mathrm{~mL}$ of anhydrous benzyl alcohol heated to $60^{\circ} \mathrm{C}$ $0.5 \mathrm{~g}$ of aminochloropyrimidine III was added. The mixture was stirred for $4 \mathrm{~h}$. After cooling to room temperature the precipitate was filtered off, the filtrate was evaporated to dryness in a vacuum. To the residue $10 \mathrm{~mL}$ of ethanol was added and concentrated to the consistency of thick oil. The oil was extracted with benzene and filtered from small amount of impurities. To the filtrate the solution of $0.79 \mathrm{~g}$ of picric acid dissolved in $5 \mathrm{~mL}$ of benzene was added, the mixture was refluxed for $15 \mathrm{~min}$, cooled to room temperature, the precipitate was filtered off, washed with benzene, and dried. After crystallization from a mixture of ethanol and DMF $(4: 1)$ the product was washed with ethanol and dried to a constant mass. Yield $0.24 \mathrm{~g}$ ( $15 \%$ to aminochloropyrimidine $\mathrm{III}), \mathrm{mp} 176^{\circ} \mathrm{C}, R_{\mathrm{f}}$ 0.89 (A). IR spectrum, $v, \mathrm{~cm}^{-1}: 607,703,738,787$, $815,911,924,941,984,1000,1027,1081,1163$, $1174,1262,1317,1334,1357,1428,1437,1474$, $1497,1510,1548,1568,1630,1654,2976,3096$, 3228, 3306, 3447. ${ }^{1} \mathrm{H}$ NMR spectrum, $\delta$, ppm: $2.38 \mathrm{~s}$ $(3 \mathrm{H}, \mathrm{Me}), 4.67 \mathrm{~d}\left(2 \mathrm{H}, \mathrm{CH}_{2} \mathrm{NH}, J 5.3 \mathrm{~Hz}\right), 5.43 \mathrm{~s}(2 \mathrm{H}$, $\left.\mathrm{CH}_{2}\right), 6.36 \mathrm{~s}(1 \mathrm{H}, \mathrm{CH}), 7.33 \mathrm{~s}(10 \mathrm{H}, \mathrm{Ph}), 8.56 \mathrm{~s}(2 \mathrm{H}$, $\mathrm{Ph}), 8.62$ br.s $(1 \mathrm{H}, \mathrm{NH})$. Found, \%: C 55.78; H 4.10; N 15.83. $\mathrm{C}_{19} \mathrm{H}_{19} \mathrm{~N}_{3} \mathrm{O} \cdot \mathrm{C}_{6} \mathrm{H}_{3} \mathrm{~N}_{3} \mathrm{O}_{7}$. Calculated, \%: C 56.18; $\mathrm{H} 4.15$; N 15.72 .

$b$. To a solution of $0.18 \mathrm{~g}$ of sodium in $15 \mathrm{~mL}$ of anhydrous benzyl alcohol heated to $60^{\circ} \mathrm{C} 0.6 \mathrm{~g}$ of benzylaminochloropyrimidine XVI was added. The mixture was stirred at $140^{\circ} \mathrm{C}$ for $4 \mathrm{~h}$, cooled to room temperature, the precipitate filtered off, the filtrate was evaporated to dryness in a vacuum. The residue was dissolved in $15 \mathrm{~mL}$ of benzene, the solution was filtered from small impurities and decanted from a small amount of tick oily substance. To the solution, $0.85 \mathrm{~g}$ of picric acid was added and the obtained mixture was refluxed for $15 \mathrm{~min}$. After cooling to room temperature the precipitate was filtered off, washed with benzene, and dried. After crystallization from a mixture of ethanol and DMF $(4: 1)$ the product was washed with ethanol and dried to a constant mass. Yield $0.68 \mathrm{~g}$ (50\% to benzylaminochloropyrimidine XVI).
2-Amino-3-benzyl-6-methylpyrimidin-4(3H)-one (XVII). The precipitate separated from the acetonitrile solution (see the synthesis of compound IId) was crystallized from $40 \%$ ethanol and dried to a constant mass. Yield $63 \mathrm{mg}, \mathrm{mp} 211^{\circ} \mathrm{C}, R_{\mathrm{f}} 0.43$ (D). IR spectrum, $v, \mathrm{~cm}^{-1}: 1688,1681 \mathrm{~s}(\mathrm{C}=\mathrm{O}), 1649,1644 \mathrm{~s}$ $\left(\mathrm{NH}_{2}\right) .{ }^{1} \mathrm{H}$ NMR spectrum, $\delta$, ppm: $2.04 \mathrm{~s}(3 \mathrm{H}, \mathrm{Me})$, $5.11 \mathrm{~s}\left(2 \mathrm{H}, \mathrm{CH}_{2}\right), 5.53 \mathrm{~s}(1 \mathrm{H}, \mathrm{CH}), 6.97 \mathrm{~s}\left(2 \mathrm{H}, \mathrm{NH}_{2}\right)$, 7.19-7.29 m (5H, Ph). Found, \%: C 66.61; H 5.89; N 19.46. $\mathrm{C}_{12} \mathrm{H}_{13} \mathrm{~N}_{3} \mathrm{O}$. Calculated, \%: C 66.96; H 6.09; N 19.52 .

\section{ACKNOWLEDGMENTS}

The authors are grateful to V.V. Tets with coworkers (Pavlov First St. Petersburg State Medical University) for performing microbiological tests.

\section{REFERENCES}

1. Liu, X. and Xu, L., Shandong Yike Daxue Xuebao, 1993, vol. 31 , no. 2, p. 176; C. A., 1994, vol. 120, 54509n.

2. Liu, X.Y. and Xu, L.J., Yaoxue Xuebao, 1994, vol. 29, no. 2, p. 153; C. A., 1994, vol. 121, $108682 \mathrm{e}$.

3. Orzeszko, B., Laudi, A.E., Starosciak, B.J., Orzeszko, A., and Kazimierczuk, Z., Acta Polon. Pharm., 2004, vol. 61 , no. 6, p. 455.

4. Feldman, I.Kh. and Kheifits, G.M., Zh. Obshch. Khim., 1961, vol. 31, no. 3, p. 755.

5. Koppel, H.C., Springer, R.H., Robins, R.K., and Cheng, C.C., J. Org. Chem., 1961, vol. 26, no. 3, p. 792. DOI: 10.1021/jo01062a037.

6. Erkin, A.V. and Krutikov, V.I., Russ. J. Gen. Chem ., 2012, vol. 82, no. 9, p. 1567. DOI: 10.1134/ S1070363212090198.

7. Gabriel, S. and Colman, J., Ber., 1899, vol. 32, no. 3, p. 2921. DOI: 10.1002/cber18990320352.

8. Polonovski, M. and Schmitt, H., Bull. Soc. chim. France, 1950, nos. 7-8, p. 616.

9. Felczak, K., Bretner, M., Kulikowski, T., and Shugar, D., Nucleosides \& Nucleotides, 1993, vol. 12, no. 2, p. 245. DOI: 10.1080/07328319308021210.

10. Marshall, J.R. and Walker, J., J. Chem. Soc., 1951, no. 4, p. 1004.

11. Organic Syntheses, Moscow: Inostrannaya Literatura, 1956, vol. 7, p. 39.

12. Erkin, A.V., Krutikov, V.I., and Smirnova, E.B., Russ. J. Gen. Chem ., 2008, vol. 78, no. 10, p. 1944. DOI: 
10.1134/S1070363208100216.

13. Sprinzak, Y., J. Am. Chem. Soc., 1956, vol. 78, no. 13, p. 3207. DOI: 10.1021/ja01594a064.

14. Bolhofer, W.A., USA Patent 4144338, 1979; C. A., 1979, vol. 91, p. 20548s.

15. Chun-Ho Wong, Wing-Shong Chan, Chui-Man Lo, Hak-Fun Chow, To Ngai, Ka-Wai Wong, Macromolecules, 2010 , vol. 43 , no. 20, p. 8389. DOI: $10.1021 / \mathrm{ma101647 \textrm {j } .}$

16. Sheldrick, G.M., Acta Crystallogr. A, 2008, vol. 64, no. 1, p. 112. DOI: 10.1107/S0108767307043930.

17. Dolomanov, O.V., Bourhis, L.J., Gildea, R.J., Howard, J.A.K., and Puschmann, H., J. Appl. Crystallogr., 2009, vol. 42, no. 2, p. 339. DOI: 10.1107/ S0021889808042726.

18. CrysAlisPro, Agilent Technologies, Ver. 1.171.36.20 (release 27-06-2012).

19. Weygand-Hilgetag. Organisch-Chemische Experimentierkunst, Moscow: Khimiya, 1968, p. 137. 